\title{
EFFECT OF A BITTER BOLUS ON ORAL, PHARYNGEAL AND ESOPHAGEAL TRANSIT OF HEALTHY SUBJECTS
}

\author{
Leda Maria Tavares ALVES, Marie SECAF and Roberto Oliveira DANTAS
}

\begin{abstract}
Context - During swallowing, boluses stimulate sensory receptors of the oral, pharyngeal, laryngeal, and esophageal regions. Sweet and tasteless foods are more acceptable for swallowing than bitter foods. A bitter bolus is unpleasant for most subjects. Our hypothesis was that the ingestion of a bitter bolus might alter the oral behavior, pharyngeal and esophageal transit when compared to a sweet bolus. Objective - To evaluate whether the bitter taste of a liquid bolus causes alteration on oral, pharyngeal and/or esophageal transit in normal subjects in comparison with sweet bolus. Method - Scintigraphic evaluation of oral, pharyngeal and esophageal transit was performed in 43 asymptomatic subjects, 22 women and 21 men, ages 23-71 years, without problems with the ingestion of liquid and solid foods, and without digestive, cardiac or neurologic diseases. Each subject swallowed in random sequence and at room temperature $5 \mathrm{~mL}$ of a liquid bolus with bitter taste, prepared with $50 \mathrm{~mL}$ of water with $2 \mathrm{~g}$ of leaves of $P e u$ mus boldus, heated until boiling (boldus tea), and $5 \mathrm{~mL}$ of a liquid bolus with sweet taste, prepared with $50 \mathrm{~mL}$ of water with $3 \mathrm{~g}$ of sucrose, both labeled with $37 \mathrm{MBq}$ of technetium phytate ( $\left.\mathrm{Tc}^{99 \mathrm{~m}}\right)$. Results - There was no difference between the bitter bolus and the sweet bolus in mouth, pharynx and esophageal transit and clearance duration and in the amount of residues. Conclusion - A bitter bolus, considered an unpleasant bolus, does not alter the duration of oral, pharyngeal and esophageal phases of swallowing, when compared with a sweet bolus, considered a pleasant bolus.
\end{abstract}

HEADINGS - Taste. Deglutition. Gastrointestinal transit.

\section{INTRODUCTION}

During swallowing, boluses stimulate sensory receptors of the oral, pharyngeal, laryngeal, and esophageal regions ${ }^{(10)}$. The stimulus of taste has influence on the coordination between breathing and swallowing, duration of oral preparation of the bolus and contraction of muscles in the submental region ${ }^{(9)}$.

Oral cavity anesthesia changes the swallow, which is influenced by chemical and sensory stimuli( ${ }^{(3)}$. The perception of sour and bitter tastes enables detection of foods not adequate for ingestion. However, some individuals cannot perceive bitter taste. Subjects with no perception of bitter taste are less resistant to venction-induced motion sickness and nausea, symptoms which are considered another way to avoid the ingestion of potentially harmful foods ${ }^{(2)}$.

Sweet and tasteless foods are more acceptable for swallowing than bitter and sour foods ${ }^{(10)}$. A bitter taste is unpleasant for most subjects ${ }^{(8,12)}$, and the perception of this bolus taste is part of the defense system against inadvertent toxin ingestion ${ }^{(2)}$. Ingestion of a bitter bolus might influence swallowing and alter the oral, pharyngeal and esophageal transit. However, there are results showing that a bitter taste bolus does not alter the durations of the oral, oropharyngeal and pharyngeal phases of swallowing of normal subjects, compared with other basic tastes ${ }^{(10)}$.

In this investigation, we evaluated the effect of a tea of Peumus boldus, frequently used in popular medicine $^{(13)}$, which has a bitter taste, on oral, pharyngeal and esophageal transit, compared with the swallow of a sweet bolus. Our hypothesis was that the unpleasant bitter taste of this tea causes alteration of oral, pharyngeal and/or esophageal transit in normal subjects, when compared with the swallow of a sweet bolus.

\section{METHODS}

Scintigraphic evaluation of oral, pharyngeal and esophageal transit was performed in 43 asymptomatic subjects, 22 women and 21 men, ages 23-71 years, median 49 years, without problems with the ingestion of liquid and solid foods, and without digestive, cardiac or neurologic diseases. The study was approved by the Ethics Committee of the Medical School of Ribeirão 
Preto, University of São Paulo, Ribeirão Preto, SP, Brazil, and written informed consent was obtained from all subjects.

Scintigraphic evaluation of transit was performed with a large-field-of-view Sopha Vision DST gamma camera (Sopha Medical Vision America, Twesburgh, OH, USA) with a low-energy all-purpose collimator. The images were analyzed with a computer (Sopha Medical Vision Powerstation).

The subjects were studied while sitting in front of the collimator of the gamma camera, facing forward, head at midline, and not moving during acquisition. An external radioactive reference of the transition between pharynx and esophagus consisting of a needle filled with liquid technetium was attached to the skin of the neck over the cricoid cartilage. The subjects were instructed to swallow the bolus in a single swallow within 2 seconds of the beginning of the recording and not to move during the recording period. A series of images of each swallow was acquired at 20 frames/second during 20 seconds for a total of 400 frames. Between recording sequences the subjects were given a sip of unlabeled water to drink to wash out any isotope and bolus taste remaining in the mouth, pharynx or esophagus from a previous swallow. Each subject swallowed in random sequence $5 \mathrm{~mL}$ of a liquid bolus with bitter taste, prepared with $50 \mathrm{~mL}$ of water with $2 \mathrm{~g}$ of leaves of Peumus boldus, heated until boiling, and $5 \mathrm{~mL}$ of a liquid bolus with sweet taste, prepared with $50 \mathrm{~mL}$ of water with $3 \mathrm{~g}$ of sucrose, both labeled with $37 \mathrm{MBq}$ of technetium phytate $\left(\mathrm{Tc}^{99 \mathrm{~m}}\right)$. The $\mathrm{pH}$ of the bitter bolus was 6.0 and the sweet bolus was 6.9. The boluses were offered at room temperature $\left(23^{\circ} \mathrm{C}\right)$. After the swallow, the subjects were asked whether the taste of the bolus they swallowed was bitter or sweet. Mouth, pharyngeal and esophageal transit were analyzed after the delineation of regions of interest (ROI). Mouth was the area with the bolus inside before the swallow. Pharynx was the area between the mouth and the external reference. The esophagus was the area between the projection of the external reference and the stomach. Three segments of the same size were delineated on the esophageal projection, i.e., proximal, middle and distal esophagus.

Time-activity curves were generated for the mouth, pharynx, proximal, middle and distal esophageal ROIs. From these time-activity curves we measured the oral transit duration and residues, the pharyngeal transit duration, clearance duration, residues, and esophageal transit, clearance and residues with the computer program of the nuclear medicine equipment. Residue was defined as the counts remaining in each ROI after the swallow, expressed as the percentage of the counts delivered to each ROI. Transit duration was defined as the interval between the maximal counts and the completion of emptying seen in a ROI. Clearance was the total exposure to the bolus in a ROI, which represents the interval between the arrival of the bolus head into the ROI and the departure of the bolus tail from the ROI. The definition of these ROIs and of the measurements performed were previously described and shown ${ }^{(1,6,7,16)}$.

The statistical analysis of transit and clearance times and the amount of residues was made using a linear model with mixed effects ${ }^{(14)}$. The tests were performed at the Center of
Quantitative Analysis of the Medical School of Ribeirão Preto USP. The results are reported as mean and standard error, unless stated otherwise.

\section{RESULTS}

The identification of the bolus taste was successfully performed by $89 \%$ of the subjects with the sweet bolus and $80 \%$ of the subjects with the bitter bolus. These individuals described the tea as having an unpleasant taste. There was no difference between the bitter bolus and the sweet bolus $(P>0.05)$ in mouth, pharynx and esophageal transit and clearance duration (Table 1), and in the amount of residues (Table 2). Identification of the bolus taste did not cause differences in the duration of the phases of swallowing or in the amount of residues.

TABLE 1. Mouth transit, pharyngeal and esophageal transit and clearance duration, in seconds, after swallowing a $5 \mathrm{~mL}$ bolus with a bitter taste and a $5 \mathrm{~mL}$ sweet bolus, performed by 43 normal subjects. Mean (SEM)

\begin{tabular}{cccc}
\hline & Bitter & Sweet & $P$ \\
\hline Mouth & $0.60(0.05)$ & $0.58(0.05)$ & 0.61
\end{tabular}

Pharyngeal

Transit

$0.37(0.02) \quad 0.36(0.02)$

0.69

Clearance

$0.68(0.03)$

$0.67(0.03)$

0.76

Esophageal proximal

Transit

$1.02(0.07)$

$1.21(0.08)$

0.08

Clearance

$1.35(0.07)$

$1.52(0.09)$

0.11

Esophageal middle

Transit

$2.49(0.44)$

$2.39(0.17)$

0.46

Clearance

$3.63(0.43)$

$3.57(0.20)$

0.76

Esophageal distal

$\begin{array}{llll}\text { Transit } & 2.90(0.69) & 1.80(0.23) & 0.40 \\ \text { Clearance } & 7.01(0.84) & 5.69(0.29) & 0.69\end{array}$

TABLE 2. Mouth, pharynx and esophageal residues, in percentage of the maximal counts measured at each ROI, after swallowing of a $5 \mathrm{~mL}$ bolus with a bitter taste, and a $5 \mathrm{~mL}$ bolus with sweet taste, performed by 43 normal subjects. Mean (SEM)

\begin{tabular}{lccc}
\hline & Bitter & Sweet & $P$ \\
\hline Mouth & $13.24(1.29)$ & $12.77(1.28)$ & 0.65 \\
Pharynx & $7.18(0.78)$ & $6.84(0.76)$ & 0.62 \\
Esophageal proximal & $6.02(0.55)$ & $5.04(0.46)$ & 0.07 \\
Esophageal midlle & $12.35(2.42)$ & $9.77(1.08)$ & 0.62 \\
Esophageal distal & $18.50(2.56)$ & $12.64(1.17)$ & 0.07 \\
\hline
\end{tabular}




\section{DISCUSSION}

Peumus boldus tea ("chá de boldo") is used for treatment of digestive and hepatic diseases in popular and homeopathic medicine. The leaves have $0.4 \%$ to $0.5 \%$ of alkaloids, with boldine as the principal alkaloid, taninos, essential oils, flavanoides, glicolipides and catequinas. It has antioxidant properties and has interaction with some drugs. Infrequent toxic effect is observed ${ }^{(13)}$. The subjects who drink the tea found it an unpleasant beverage, which agrees with the results that show that bitter taste is unpleasant for humans ${ }^{(8,12)}$.

In the evaluation of the recognition of bolus taste, $94 \%$ of the subjects were found to recognize the sweet bolus (sucrose) and $91 \%$ recognized the bitter bolus (quinine sulfate) $)^{(12)}$, results similar to our study. Previous publication described that bitter bolus was the taste more clearly recognized and that there was no difference in taste identification between men and women ${ }^{(4)}$.

In the evaluation of the five basic tastes using a hedonic scale ranging from 0 (highly pleasant) to 10 (highly unpleasant) the sweet taste scored $2.9 \pm 2.2$ and the bitter taste $9.8 \pm$ 0.6 . The pleasant sweet taste induced the weakest autonomic nervous system response whereas the unpleasant bitter taste induced the strongest response ${ }^{(12)}$. Foods with sweet taste are more acceptable for swallowing than foods with bitter taste ${ }^{(10)}$. Taking into consideration these observations, we expected that the bitter taste bolus might cause different transit duration response than other bolus taste. However, differences in oral, pharyngeal, and esophageal transit duration and amount of residues between sweet and bitter bolus were not found.

The chemical sense is a mechanism against inadvertent toxin ingestion. The perception of bitter taste enables detection of potentially harmful foods $s^{(2)}$. There is a strong genetic component to the perception of bitter taste. About $35 \%$ of the population can not recognize certain bitter substances due to variations in the TAS2R gene family of G protein-coupled taste receptors ${ }^{(5)}$.

Although the subjects perceived an unpleasant taste, their swallow does not differ from that of a pleasant taste.
In normal subjects, the swallow has a sequence of events and timing which does not change in function of the bolus taste $^{(10)}$. The central mechanisms of swallowing control cause the same response that is independent of bolus taste. Swallowing should be avoided in the control of harmful food ingestion, but after swallowing, the sequence and timing is the same of a pleasant food taste.

Bitter taste cause a decrease in skin blood flow ${ }^{(8)}$, and a stronger autonomic nervous system response compared with other tastes ${ }^{(12)}$. These responses do not alter swallowing. However, in the proximal esophageal body, the results suggested that the transit duration might be shorter and the amount of residues might be larger with the bitter bolus than with the sweet bolus, but the results did not reach statistical significance $(P=0.08$ for transit duration and $P=0.07$ for the amount of residues). The same was observed in the distal esophagus where the amount of residues was larger with the bitter bolus than with the sweet bolus, but we can not have a precise conclusion about that because statistical analysis found a $P=0.08$. The hypothesis that a bitter bolus can have influence on esophageal transit needs more investigations, and perhaps, another methodology of evaluation.

The results of this investigation agree with a previous study that evaluated the oral and pharyngeal transit duration using quinine hydrochloride as a bitter bolus ${ }^{(10)}$. There was no reference of the $\mathrm{pH}$ of this substance and esophageal transit was not evaluated. A low $\mathrm{pH}$ of the bolus causes a longer transit duration in the distal esophagus ${ }^{(1)}$.

Scintigraphy is a reliable technique to measure oral-pharyngeal ${ }^{(15)}$ and esophageal ${ }^{(10)}$ phases of swallowing. In the mouth and pharynx, scintigraphic transit times do not differ from times measured radiographically, have a good test-retest reliability, and abnormal oral and pharyngeal residues have high positive predictive values ${ }^{(15)}$. In the esophagus, the scintigraphic method quantitatively measures the ability of the esophagus to move a fluid bolus from mouth to the stomach ${ }^{(11)}$.

We concluded that a bitter bolus, considered an unpleasant bolus taste, does not differ in the duration of oral, pharyngeal and esophageal phases of swallowing, when compared with a sweet bolus, considered a pleasant bolus taste.

Alves LMT, Secaf M, Dantas RO. Efeito do bolo amargo no trânsito oral, faríngeo e esofágico de pessoas normais. Arq Gastroenterol. 2013;50(1):31-4. RESUMO - Contexto - Durante a deglutição o bolo estimula os receptores sensoriais da boca, faringe, laringe e esôfago. Os alimentos doces e sem gosto são mais aceitáveis para a deglutição do que os alimentos amargos, que tem gosto desagradável para a maioria dos indivíduos. A hipótese destes autores era que a ingestão de um bolo amargo pode alterar o trânsito oral, faríngeo e esofágico. Objetivo - Avaliar se o gosto amargo de um bolo líquido provoca alteração do trânsito oral, faringeo e/ou esofágico de pessoas normais. Método - Avaliação cintilográfica dos trânsitos oral, faringeo e esofágico foi realizada em 43 indivíduos assintomáticos, 22 mulheres e 21 homens, com idades entre 23-71 anos, sem problemas com a ingestão de alimentos líquidos e sólidos, sem doença digestiva, cardíaca ou neurológica. Cada indivíduo ingeriu, em sequência aleatória e na temperatura ambiente, $5 \mathrm{~mL}$ de um bolo líquido com sabor amargo, preparado com $2 \mathrm{~g}$ de folhas de Peumus boldus em $50 \mathrm{~mL}$ de água, aquecidas até a temperatura de fervura (chá de boldo), e $5 \mathrm{~mL}$ de um bolo líquido com sabor doce, preparado com $3 \mathrm{~g}$ de sacarose em $50 \mathrm{~mL}$ de água, ambos marcados com $37 \mathrm{MBq}$ de tecnécio fitato $\left(\mathrm{Tc}^{99 \mathrm{~m}}\right)$. Resultados - Não houve diferença entre o bolo amargo e o bolo doce na duração do trânsito pela boca, faringe e esôfago, e na quantidade de resíduos. Conclusão - Um bolo amargo, considerado de sabor desagradável, não altera a duração das fases oral, faríngea e esofágica da deglutição, quando comparado com um bolo doce, considerado como sabor agradável.

DESCRITORES - Paladar. Deglutição. Trânsito gastrointestinal. 


\section{REFERENCES}

1. Alves LM, Fabio SR, Dantas RO. Effect of bolus taste on the esophageal transit in patients with stroke. Dis Esophagus. 2012. doi: 10.1111/j.1442-2050.2012.01366.x.

2. Benson PW, Hooker JB, Koch KL, Weinberg RB. Bitter taster status predicts susceptibility to venction-induced motion sickness and nausea. Neurogastroenterol Motil. 2012;24:134-e86. doi: 10.1111/j.1365-2982.2011.01842.x.

3. Chee C, Arshad S, Singh S, Mistry S, Hamdy S. The influence of chemical gustatory stimuli and oral anesthesia on healthy human pharyngeal swallowing. Chem Senses. 2005;30:393-400.

4. Costa MM, Santana E, Almeida J. Oral taste recognition in health volunteers. Arq Gastroenterol. 2010;47:152-8.

5. Drayna D. Human taste genetics. Annu Rev Genomics Hum Genet. 2005;6:217-35.

6. Gomes FR, Secaf M, Kubo TTA, Dantas RO. Oral and pharyngeal transit of a paste bolus in Chagas' disease. Dysphagia. 2008;23:82-7.

7. Issa Okubo Pde C, Dantas RO, Troncon LEA, Moriguti JC, Ferriolli E. Clinical and scintigraphic assessment of swallowing of older patients admitted to a tertiary care geriatric ward. Dysphagia. 2008;23:1-6.

8. Kashima H, Hayashi N. Basic taste stimuli elicit unique responses in facial skin blood flow. PLoS One. 2011;6:e28236.
9. Leow LP, Huckabee ML, Sharma S, Tooley TP. The influence of taste on swallowing apnea, oral preparation time, and duration and amplitude of submental muscle contraction. Chem Senses. 2007;32:119-28.

10. Miyaoka Y, Haishima K, Takagi M, Haishima H, Asari J, Yamada Y. Influences of thermal and gustatory characteristics on sensory and motor aspects of swallowing. Dysphagia. 2006;21:38-48.

11. Nakajima K, Hasegawa M, Inaki A, Wakabayashi H, Hosoya T, Takehara K, Kinuya S. Esophageal transit study using a sliding sum image: application to patients with probable and definite systemic sclerosis. Ann Nucl Med. 2011;25:325-31.

12. Rousmans S, Robin O, Dittmar A, Vernet-Maury E. Autonomic nervous system responses associated with primary tastes. Chem Senses. 2000;25:709-18.

13. Ruiz ALTG, Taffarello D, Souza VHS, Carvalho JE. Farmacologia e toxicologia de Peumus boldus e Baccharis genistelloides. Rev Bras Farmacogn. 2008;8:295-300.

14. Schall R. Estimation in generalized linear models with random effects. Biometrika. 1991;78:719-27.

15. Shaw DW, Williams RBH, Cook IJ, Wallace KL, Weltman MD, Collins PJ, Mckay E, Smart R, Simula ME. Oropharyngeal scintigraphy: a reliable technique for the quantitative evaluation of oral-pharyngeal swallowing. Dysphagia. 2004; $19: 36-42$.

16. Silva AC, Fabio SRC, Dantas RO. A scintigraphic study of oral, pharyngeal, and esophageal transit in patients with stroke. Dysphagia. 2008;23:165-71.

Received 17/8/2012. Accepted 18/9/2012 